\section{Pacific Northwest}

National Laboratory

Operated by Battelle for the

U.S. Department of Energy

\title{
Installation of a Hydrologic Characterization Network for Vadose Zone Monitoring of a Single-Shell Tank Farm at the U.S. Department of Energy Hanford Site
}

\author{
G.W. Gee \\ A.L. Ward \\ J.C. Ritter \\ Pacific Northwest National Laboratory \\ Richland, Washington \\ J.B. Sisson \\ J.M. Hubbell \\ Idaho National Engineering and Environmental Laboratory \\ Idaho Falls, Idaho \\ Harold Sydnor \\ CH2M Hill Hanford Group \\ Richland, Washington
}

October 2001

Prepared for the U.S. Department of Energy under Contract DE-AC06-76RL01830 


\title{
DISCLAIMER
}

This report was prepared as an account of work sponsored by an agency of the United States Government. Neither the United States Government nor any agency thereof, nor Battelle Memorial Institute, nor any of their employees, makes any warranty, express or implied, or assumes any legal liability or responsibility for the accuracy, completeness, or usefulness of any information, apparatus, product, or process disclosed, or represents that its use would not infringe privately owned rights. Reference herein to any specific commercial product, process, or service by trade name, trademark, manufacturer, or otherwise does not necessarily constitute or imply its endorsement, recommendation, or favoring by the United States Government or any agency thereof, or Battelle Memorial Institute. The views and opinions of authors expressed herein do not necessarily state or reflect those of the United States Government or any agency thereof.

\author{
PACIFIC NORTHWEST NATIONAL LABORATORY \\ operated by \\ BATTELLE \\ for the \\ UNITED STATES DEPARTMENT OF ENERGY \\ under Contract DE-ACO6-76RLO183O \\ Printed in the United States of America \\ Available to DOE and DOE contractors from the \\ Office of Scientific and Technical Information, \\ P.O. Box 62, Oak Ridge, TN 37831-0062; \\ ph: (865) 576-8401 \\ fax: (865) 576-5728 \\ email: reports@adonis.osti.gov

\footnotetext{
Available to the public from the National Technical Information Service, U.S. Department of Commerce, 5285 Port Royal Rd., Springfield, VA 22161 ph: (800) 553-6847 fax: (703) 605-6900

email: orders@ntis.fedworld.gov

online ordering: http://www.ntis.gov/ordering.htm
}

(3) This document was printed on recycled paper. 


\section{Installation of a Hydrologic Characterization Network for Vadose Zone Monitoring of a Single-Shell Tank Farm at the U. S. Department of Energy Hanford Site}

G. W. Gee

A. L. Ward

J. C. Ritter

Pacific Northwest National Laboratory

Richland, Washington

J. B. Sisson

J. M. Hubbell

Idaho National Engineering and Environmental Laboratory

Idaho Falls, Idaho

Harold Sydnor

CH2M Hill Hanford Group

Richland, Washington

October 2001

Prepared for the U.S. Department of Energy

under Contract DE-AC06-76RL01830

Pacific Northwest National Laboratory

Richland, Washington 99352 


\section{Summary}

The Pacific Northwest National Laboratory, in collaboration with the Idaho National Engineering and Environmental Laboratory and Duratek Federal Services, deployed a suite of vadose-zone instruments at the B Tank Farm in the 200 E Area of the Hanford Site, near Richland, Washington, during the last quarter of FY 2001. The work was supported by the U. S. Department of Energy's Office of Science and Technology Subsurface Focus Area under Project RL31SS31. The purpose of the deployment was to obtain in situ hydrologic characterization data within the vadose zone of a high-level-waste tank farm. Eight sensor nests, ranging in depth from $67 \mathrm{~m}(220 \mathrm{ft})$ below ground surface (bgs) to $0.9 \mathrm{~m}(3 \mathrm{ft}) \mathrm{bgs}$ were placed in contact with vadose-zone sediments inside a recently drilled, uncased, borehole (C3360) located adjacent to Tank B-110. The sensor sets are part of the Vadose Zone Monitoring System and include advanced tensiometers, heat dissipation units, frequency domain reflectometers, thermal probes, and vadose zone solution samplers. Within the top meter of the surface, a water flux meter was deployed to estimate net infiltration from meteoric water (rain and snowmelt) sources. In addition, a rain gage was located within the tank farm to document on-site precipitation events. All sensor units, with the exception of the solution samplers, were connected to a solar-powered data logger located within the tank farm. Data collected from these sensors are currently being accessed by modem and cell phone and will be analyzed during the coming year (FY 2001). 


\section{Acknowledgments}

The deployment of a vadose-zone monitoring network for hydrologic characterization is the first of its kind at a Hanford Tank Farm. The work was supported by the Department of Energy's Office of Science and Technology, Subsurface Contamination Focus Area, under Project RL31SS31. The deployment was successful because of excellent cooperation by CH2M Hill Hanford Group (CHG), who allowed the $\mathrm{C} 3360$ borehole to be used for hydrologic monitoring purposes. The characterization borehole C3360 is part of the B Tank Farm SST Phase 1 RFI/CMS activities. The CHG activity was supported by the U. S. Department of Energy's Office of River Protection through the Tank Farm Vadose Zone Project. We thank Tony Knepp, Harold Sydnor and David Myers of CHG for providing us the window of opportunity for this deployment and allowing us to impose on their drilling and operations schedule. We also acknowledge the invaluable help of Kent Reynolds and Dave Skoglie of Duratek, who made the instrument placement in the $\mathrm{C} 3360$ borehole possible with keen oversight and useful suggestions. We thank Joe Lord of INEEL and Jason Ritter of PNNL, who provided installation support and data-logger programs needed for remote access to the monitoring network. We also thank tank farm operations support staff, who assisted in the sensor placement. 


\section{Contents}

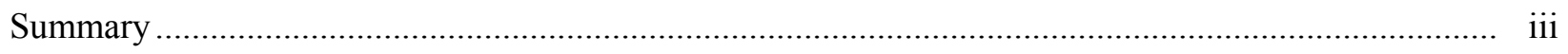

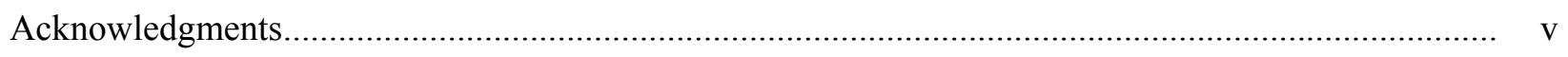

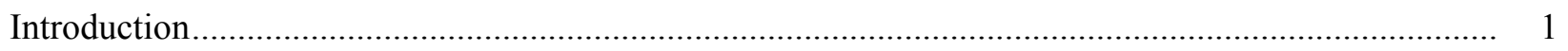

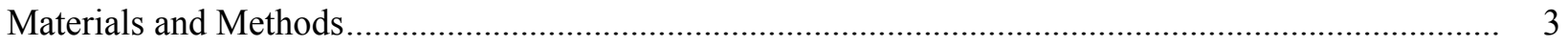

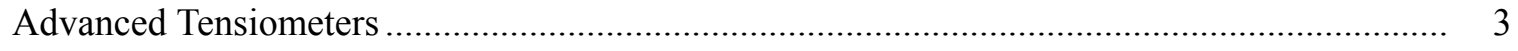

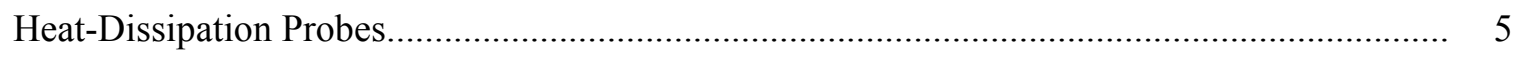

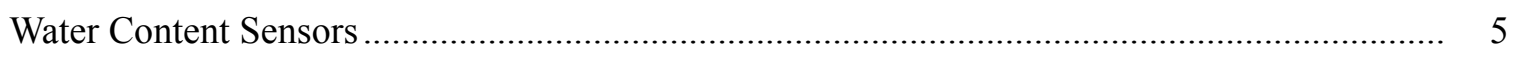

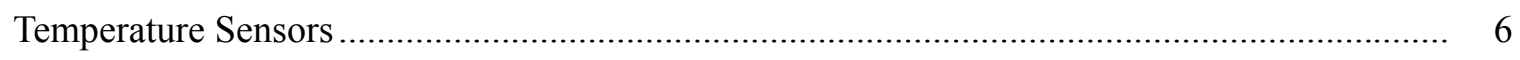

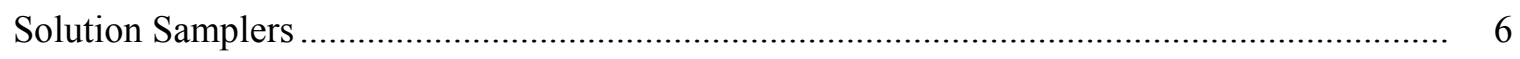

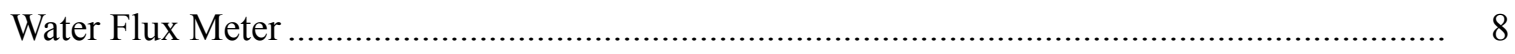

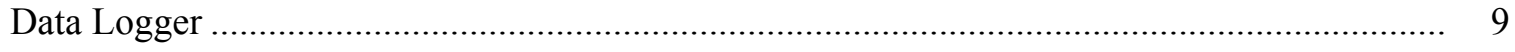

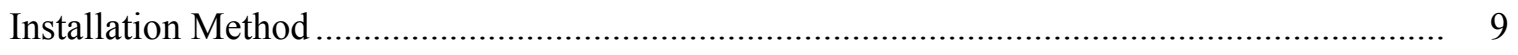

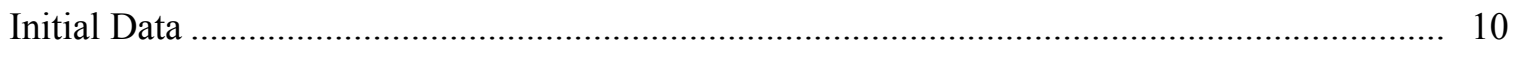

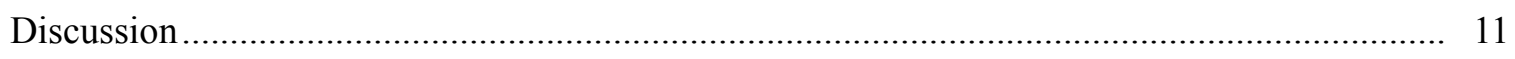

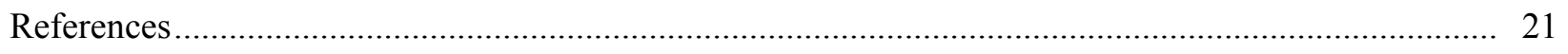

APPENDIX A: Calibration Data for VZMS Sensors ................................................................. A.1

APPENDIX B: Duratek Water Well Report for C-3360 (299-E33-46) …............................................. B.1 


\section{Figures}

1. Schematic of Advanced Tensiometers Showing the Porous Cup and Pressure Transducer System for a Typical Deployment ......................................................................................

2. Heat Dissipation Unit (HDU) for Measuring Capillary Pressures ............................................ 6

3. Water Content Sensor Modified from the CSI 505 (CSI, Logan, Utah) ..................................... 7

4. Vadose-Zone Monitoring System (Without Water Flux Meter and Temperature Sensor) Before Deployment in B Tank Farm .............................................................................. 8

5. Schematic Cross Section of PNNL Water Flux Meter ...................................................... 9

6. Capillary Pressure Data from the C-3660 Borehole near Tank B110 in B Tank Farm.................... 12

7. Total Pressure Head Data from the C-3660 Borehole near Tank B110 in B Tank Farm .................. 13

8. Water Content Data from the C-3660 Borehole near Tank B110 in B Tank Farm.......................... 14

9. Drainage Data from the C-3660 Borehole near Tank B110 in B Tank Farm ................................ 15

10. Precipitation Data from the C-3660 Borehole near Tank B110 in B Tank Farm............................ 16

11. Soil Temperature Data from the C-3660 Borehole near Tank B110 in B Tank Farm ................... 17

12. Soil Temperature Profile from the C-3660 Borehole near Tank B110 in B Tank Farm .................. 18 


\section{Introduction}

Knowledge of the water-potential gradient and hydraulic conductivity allows the calculation of water flux over the interval of measurement in a soil profile. Measurement of the water flux can in turn be used to estimate the hydraulic properties if the water-potential gradients are known. Such data allow the dominant flow direction in the vadose zone to be identified and can quantify recharge rates, a requirement for successful interpretation of existing contaminant plumes, for history matching in model calibration and for predicting future migration. Under ideal conditions (shallow, uncontaminated vadose zones), such information is easily obtained by monitoring water content and water pressure, and in some cases, the water flux can be directly measured during controlled infiltration experiments. Because of costs and worker safety, this approach is not readily applicable to contaminated soils within the U.S. Department of Energy (DOE) complex, and more innovative techniques are needed to get at this information. Waterflow direction is best determined from water-potential gradients measured using tensiometry. However, traditional tensiometers are limited to operating within a few feet from the ground surface and are fragile, difficult to maintain, and difficult to install, particularly in contaminated sites. Advanced tensiometers, developed at the Idaho National Engineering and Environmental Laboratory (INEEL), as described later in more detail, overcome these limitations. They are more robust and easy to maintain, even at depths exceeding $15 \mathrm{~m}(50 \mathrm{ft})$. As indicated, the addition of water content and water-flux measurements to water pressure provide a very strong suite of measurements that can be used to estimate recharge rates and rates of chemical transport. When linked to a data-acquisition and telemetry system, these sensors provide real-time measurements of changes in water pressure and water contents. These data, when correlated with water-flux measurements, changes in surface boundary conditions, and episodic changes in groundwater contamination levels, would allow important driving forces and transport mechanisms in the Hanford vadose zone to be identified. A combination of sensors packaged as a vadose-zone monitoringsystem (VZMS), designed to measure the water balance, pressure gradients, and related parameters, could provide a site with necessary characterization data for evaluating vadose-zone transport. With the need for in situ hydrologic data and current cost estimates of around \$1M per borehole in tank farms, piggy backing vadose-zone monitoring systems with ongoing drilling programs can provide a very attractive option with the potential to save $\$ 10$ s of millions in characterization and monitoring costs at the Hanford Site. Similar savings can be expected at Los Alamos and INEEL.

In keeping with the overall objectives of the Subsurface Contaminant Focus Area, this project (RL31SS31) has focused on both developing and deploying instrumentation and methods that can be used to improve the hydrologic characterization of the vadose zone at the Hanford Site. One of the key areas where characterization information is needed is at tank farms where leaks of high-level waste fluids have occurred. An objective of this project is to deploy suitable vadose-zone sensors for hydrologic characterization within a tank farm at Hanford. To accomplish this objective, Pacific Northwest National Laboratory (PNNL) teamed with INEEL, Duratek, and CHG and installed a VZMS within the B Tank Farm in the $200 \mathrm{E}$ Area of the Hanford Site during the fourth quarter of FY 2001. The following sections

describe the specific sensors used, the deployment activity, the final in-place sensor configuration, and the monitoring strategy for documenting the hydrologic conditions of the subsurface at the B Tank Farm. 


\section{Materials and Methods}

In situ hydrologic characterization of the vadose zone has evolved over the past few years to include key measurements of water content, soil water (capillary) pressure, temperature and chemical concentration. Knowledge of these state variables is essential to developing a more complete understanding of vadose-zone processes and provides dynamic input to numerical model calibration and verification efforts. In addition to the state variables, soil-water-flux data are also monitored. The VZMS is used to measure the hydrologic parameters described above. While the VZMS does not provide chemical concentrations directly, it provides for obtaining soil water samples by means of a vacuum lysimeter that can be analyzed in the laboratory. Recent developments also have allowed water flux in the vadose zone to be monitored more easily. Because no single sensor is capable of monitoring all of the key variables in the vadose zone, suites of sensors are required in the VZMS. Using a suite of sensors allows for concurrent measurements of state variables and also provides the characterization and monitoring data needed to further identify flow paths and mechanisms that previously have not been considered in transport models.

During July and August 2001, a VZMS consisting of eight sets of sensors was placed in the B tank farm in well C3360 (299-E33-46), located adjacent to Tank B-110. Duratek Federal Services drilled the borehole, under the direction of CH2M Hill Hanford Group (CHG), for the purpose of chemical and hydrologic characterization as part of the SST Phase 1 RFI/CMS Characterization effort (CHG 2000). We briefly describe the sensors that were deployed and the rationale for their use for subsurface monitoring at the tank farm. Advanced tensiometers, heat-dissipation probes, water-content sensors, solution samplers, temperature sensors, and the water-flux meter are described in turn.

\section{Advanced Tensiometers}

Tensiometers (water-filled porous cups attached to a pressure transducer) are used to measure water pressures (capillary pressures) in the operational range from 0 to -700 mbar. Tensiometers can also be used to measure positive pressures in soils that are saturated and thus act as piezometers for monitoring perched water bodies or water-table elevations. Advanced Tensiometers (Sisson and Hubbell 1999) (ATs) incorporate the pressure transducer directly into the porous cup to minimize the length of the water column that hydraulically connects the pressure transducer to the cup. By minimizing the water-column length, the tensiometer performance is enhanced by virtually eliminating or minimizing several problems encountered in conventional tensiometers - namely, excessive thermal noise, sluggish response, and limited depth placement (Hubbell and Sisson 1996, 1998; Sisson and Hubbell 1999). Placement of the pressure transducer, porous cup, and the water column at depths where diurnal temperature fluctuations are dampened minimizes the problem of thermally affected fluid movement into and out of the tensiometer. In addition to reducing the noise level from temperature fluctuations, the length of time between refilling the tensiometer was extended from once per week to once per year or longer, depending on the depth of placement and the in situ capillary pressures. The short length of the sealed portion of the AT makes it possible to be placed at almost any depth (Figure 1). 

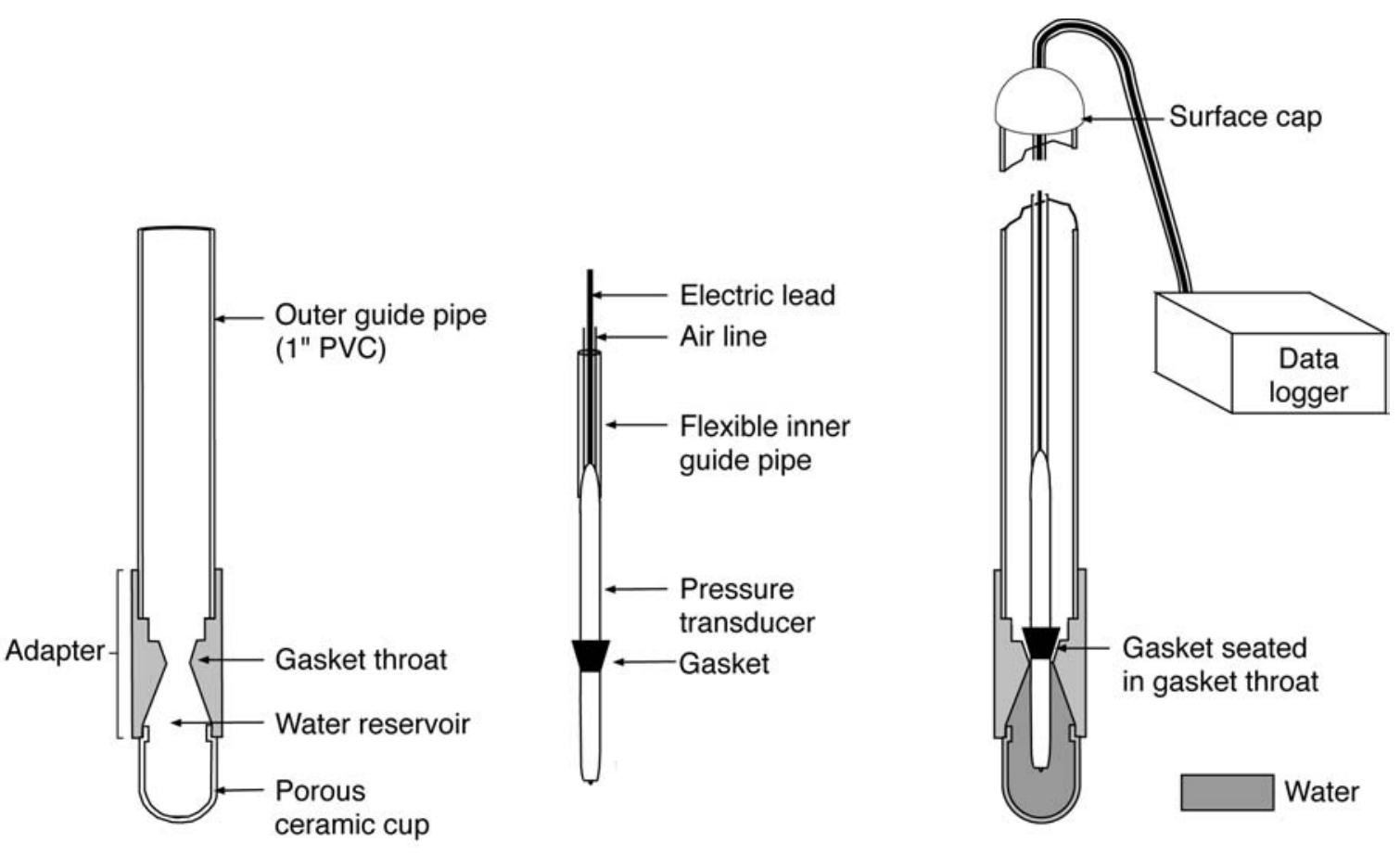

Figure 1. Schematic of Advanced Tensiometers Showing the Porous Cup and Pressure Transducer System for a Typical Deployment

Advanced tensiometers have been deployed successfully at Savannah River, Oak Ridge, and INEEL. Technical issues with respect to durability of sensors, data-acquisition systems, and reliability of data have largely been resolved. Typically, sensors have been easily installed under conditions where monitoring points have been relatively easy to access. The major technical issue for Hanford relates to deployment into contaminated sites and in deep vadose-zone materials (deeper than $15 \mathrm{~m}[50 \mathrm{ft}]$ ). Where open boreholes are available, these units can be installed in a semi-permanent installation.

The design for the Hanford Site tank farms was modified from a series of observations suggesting that for the most part, capillary pressures in Hanford sediments, are within the range of 0 to -100 mbar. Based on these anticipated pressures, the water losses from the cups should be very low and so the life of the units can be extended almost indefinitely in the wet-draining sandy sediments by optimizing the volume of water in the tensiometer. Such sediments are present in abundance in the subsurface at most Hanford waste sites. The high anticipated water potential and limited access to the site for refilling the instrument combined to make this design more applicable than the standard configuration for this particular site. Based on these observations, the tensiometer was constructed so that it could be filled and sealed in place. The basic AT design was slightly modified to remove the outer and inner guide pipe that normally extends to the land surface and enlarges the water reservoir. The pressure transducers used in the tensiometer are a type that can over-range beyond the typical pressure limit of $15 \mathrm{psi}$. The pressure sensor (Motorola MPX-4250A, Denver, Colorado) is placed adjacent to the measurement location so that no further manipulation of pressure data is required. The pressure range of the sensor will allow the detection of perched water if the sediments become saturated. Calibrations of the tensiometers are reported in Table 1. 
Table 1. VZMS Sensor Placement in Borehole C3360 near Tank B110 in B Tank Farm

\begin{tabular}{||c|c|c|c|c|c|c||}
\hline $\begin{array}{c}\text { Detph } \\
\text { (bgs) }\end{array}$ & WFM & AT & HDU & WC & Temp & SS \\
\hline 226 & & $\mathrm{X}$ & $\mathrm{X}$ & $\mathrm{X}$ & $\mathrm{X}$ & $\mathrm{X}$ \\
\hline 218 & & $\mathrm{X}$ & & $\mathrm{X}$ & $\mathrm{X}$ & $\mathrm{X}$ \\
\hline 82 & & $\mathrm{X}$ & $\mathrm{X}$ & $\mathrm{X}$ & $\mathrm{X}$ & $\mathrm{X}$ \\
\hline 53 & & $\mathrm{X}$ & & $\mathrm{X}$ & $\mathrm{X}$ & $\mathrm{X}$ \\
\hline 15 & & $\mathrm{X}$ & $\mathrm{X}$ & $\mathrm{X}$ & $\mathrm{X}$ & $\mathrm{X}$ \\
\hline 9 & & $\mathrm{X}$ & & $\mathrm{X}$ & $\mathrm{X}$ & $\mathrm{X}$ \\
\hline 6 & $\mathrm{X}$ & $\mathrm{X}$ & $\mathrm{X}$ & $\mathrm{X}$ & $\mathrm{X}$ & $\mathrm{X}$ \\
\hline 3 & & $\mathrm{X}$ & & $\mathrm{X}$ & $\mathrm{X}$ & $\mathrm{X}$ \\
\hline
\end{tabular}

\section{Heat-Dissipation Probes}

The heat-dissipation unit (HDU) is used to measure soil water pressure and is commercially available from CSI, Logan, Utah (e.g., model 229 L). The HDU consists of a special ceramic body with a temperature sensor and a heater imbedded in the center (Figure 2.).

A short heat pulse is generated in the porous ceramic, and the heat dissipation is related to the water content of the ceramic, which in turn is related uniquely to the water pressure in the surrounding media. Reece (1996) has shown that these units are quite reliable in the pressure range from -100 mbar to -10000 mbar or more. The HDU provides a redundant measure of capillary pressure and operates in a range beyond where the normal tensiometers operate (i.e., 0 to -0.7 bar). HDUs have been used successfully at Hanford in the $200 \mathrm{E}$ Area to measure water pressures in silt loam soils that cover the prototype surface barrier (Ward et al. 1997). It is expected that these units will work best in soils that have drained such that their capillary pressures are drier than -100 mbar (the typical air entry value for the porous ceramic). The HDUs were calibrated in the laboratory using Hanford sediments at three different water contents. Calibrations of the HDU units are reported in Appendix A.

\section{Water Content Sensors}

The water-content sensors were fabricated using a CS505 fuel-moisture sensor (Campbell Scientific, Logan, Utah) attached to brass electrodes mounted on a foam backing material (Figure 3). The watercontent sensor is lowered to depth, and the electrode-foam-pad assembly is forced against the borehole wall. Figure 3 is a picture of the water-content assembly. The water-content sensors were calibrated in Hanford sediments obtained at the Buried Waste Test Facility in the 400 Area Hanford, Washington. The calibration procedure consisted of packing the sensors in a $15.88-\mathrm{cm}(6.25-\mathrm{in}$.) diameter column of oven dried sediments, obtaining a sensor output, saturating the column using tap water, and then obtaining another sensor output. The two outputs were used to compute a linear calibration for each sensor. The calibration results and the location where the data can be found in the data-logger output file are presented in Appendix A. The depth to which each water-content sensor was installed is listed in Table 1. 


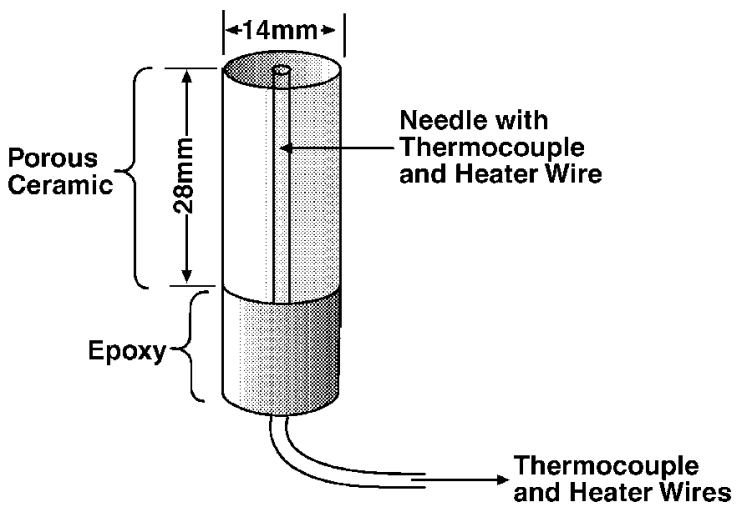

Figure 2. Heat Dissipation Unit (HDU) for Measuring Capillary Pressures

\section{Temperature Sensors}

The temperature sensors used are the AD952 solid-state precision temperature transducers (Analog Devices, Norwood, MA 02062-9106). The factory calibration curves are used to convert the sensor outputs to subsurface temperatures. The factory calibration indicates that the sensors have a precision of $\pm 0.5 \mathrm{~K}$ over the temperature range of -25 to $105^{\circ} \mathrm{C}$. The sensors have a current output of $1 \mathrm{microamp} / \mathrm{K}$, and the current was estimated by the voltage drop across a $250 \pm 0.1 \%$ ohm resistor. Thus, the calibration equation for each sensor is $\mathrm{T}\left({ }^{\circ} \mathrm{C}\right)=4 * \mathrm{mV}-273$, where the $\mathrm{mV}$ in the voltage drop across the 250 -ohm resistor is in millivolts. It should also be noted that the HDU sensor has a thermocouple (Figure 2) so that there is a redundancy in temperature measurements.

\section{Solution Samplers}

The solution samplers are standard model 1940 and 1920 solution samplers constructed with 1-bar high-flow ceramic cups (Soil Moisture Equipment Co., Santa Barbara, California). These sampling units were constructed with the upper end of the ceramic sealed with a plug that accommodates two $0.635-\mathrm{cm}$ (0.25-in.) plastic lines. The lines, which extend to the soil surface, run to an environmental box that is located beneath the data logger. The lines are used for pressurization and sample collection. When solution samples are to be collected, a negative pressure is applied for a given period of time (e.g., $0.5 \mathrm{~h}$ or longer, dependant on field conditions ), and then the line is pressurized to remove the water sample. This pressure forces the liquid sample out of the cup and up into a collection system at the surface. Since the samples are in a radiation zone and some of the samples may be radioactive, a sample procedure will be developed for sample collection and analysis before removing any samples. Sampling will be done in consultation with $\mathrm{CHG}$ for additional characterization data from the $\mathrm{B}$ tank farm arise. Figure 4 shows the VZMS system before installation in the B Tank Farm at well C3360 with the full array of instruments. Not shown in the picture are the temperature sensor and the water flux meter that is described in the following section. 


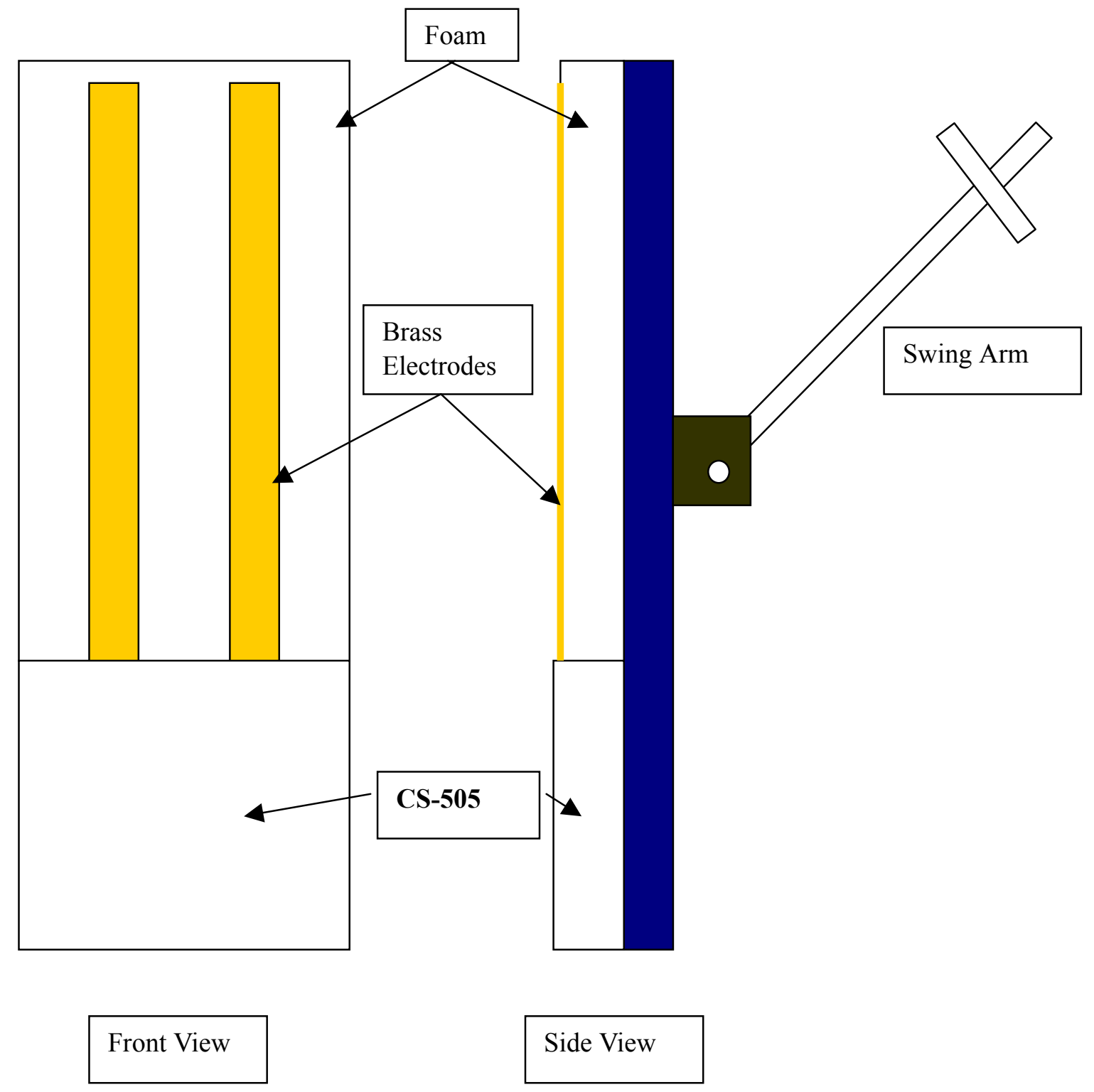

Figure 3. Water Content Sensor Modified from the CSI 505 (CSI, Logan, Utah) 


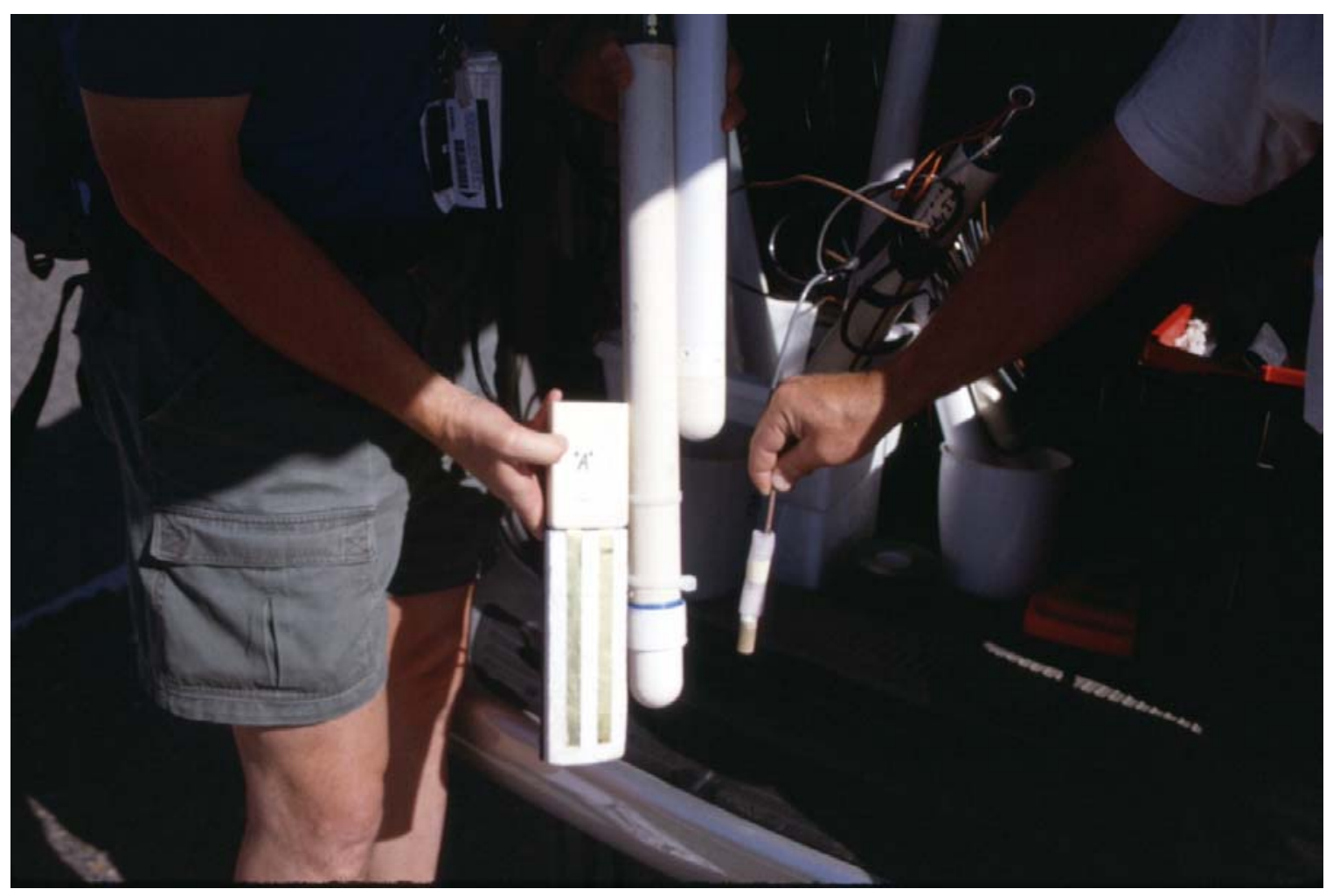

Figure 4. Vadose-Zone Monitoring System (Without Water Flux Meter and Temperature Sensor) Before Deployment in B Tank Farm. Sensors from left to right are the Modified CSI Water Content Sensor, Advanced Tensiometer, Solution Sampler, and Heat-Dissipation Unit

\section{Water Flux Meter}

Figure 5 shows an idealized cross section of the PNNL water flux meter (WFM). The WFM is similar in design to a miniature drainage lysimeter. The WFM unit allows the draining water to percolate into a glass wick that has a tension control of about 60 -mbar suction. The tension control and the extension of soil above the wick combine to limit the diversion of water around the meter, which is often one of the limitations of mini-lysimeter units. The bottom of the WFM unit was installed in the borehole at about the $1.8-\mathrm{m}(6-\mathrm{ft})$ depth. The top of the unit is $20 \mathrm{~cm}$ (8 in.) from the surface and is covered with gravel fill (i.e., the material that covers the B tank farm). No vegetation is growing on the tank farm surface, so significant drainage from winter precipitation is expected to occur at this site. The flux meter will provide the net infiltration data needed to determine the rate of flux in the near surface throughout the year. The WFM unit will require some time to equilibrate with the surrounding sediments. 


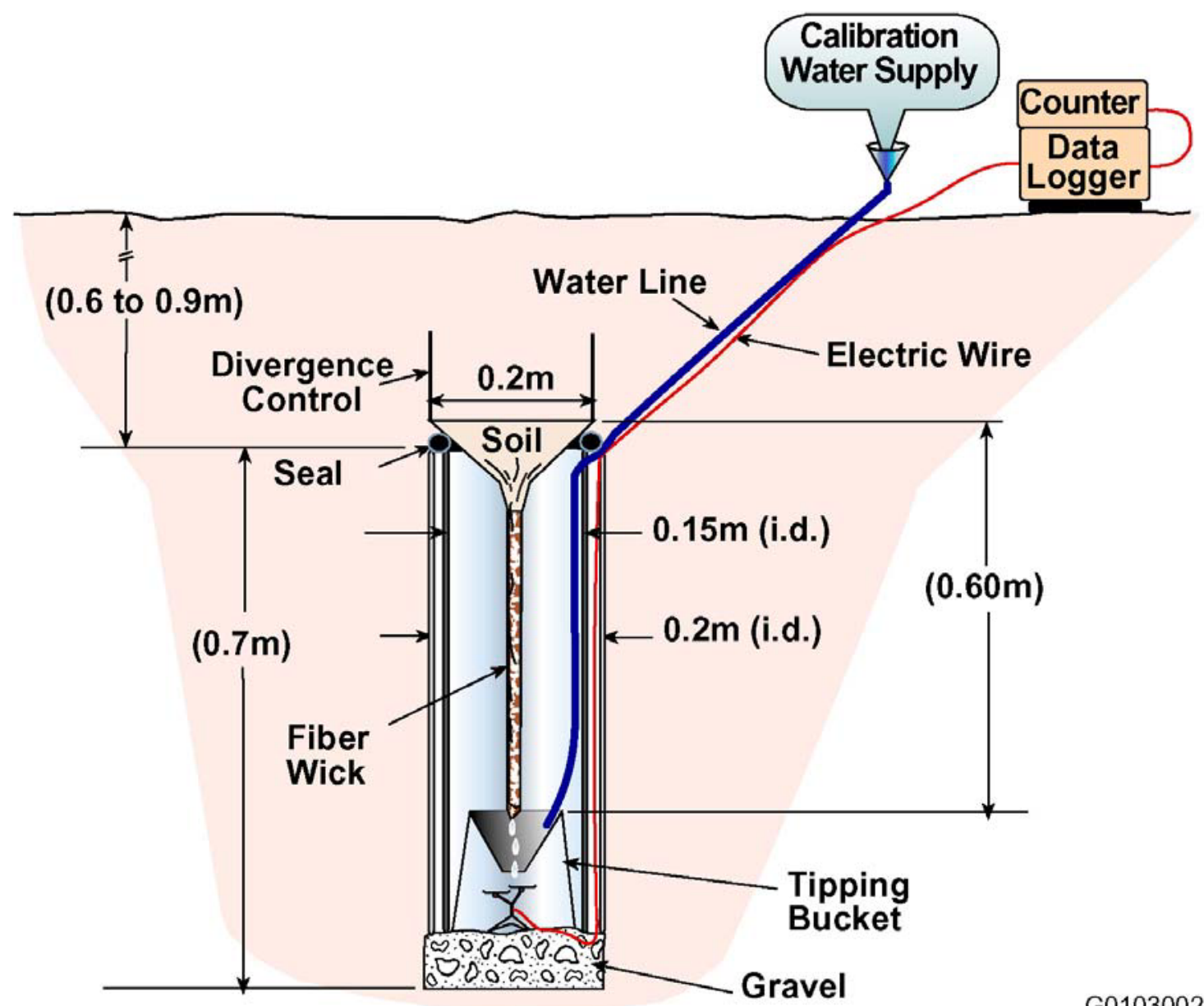

G01030028.1

Figure 5. Schematic Cross Section of PNNL Water Flux Meter. For the C3360 Borehole, the divergence control extension was $60 \mathrm{~cm}$ (2.36 in.) in length, and the top of the unit was $20 \mathrm{~cm}$ (8 in.) below the surface.

\section{Data Logger}

A Campbell Scientific CR 23 (Logan, Utah) is used to collect and store the field data from the advanced tensiometers, heat-dissipation sensors, temperature sensors (downhole and at instrument panel), and water-flux meter. Data are collected on a regular daily interval and stored in the internal memory. The data logger is powered by a battery that is recharged by a solar panel so that it is not affected by power outages. The data can be accessed using a cellular phone for remote data collection. The entire package has been designed to allow continuous long-term unattended data collection, required for detecting episodic infiltration events, characteristic of arid sites.

\section{Installation Method}

The starting condition of the borehole was a freshly drilled $0.2-\mathrm{m}(0.66-\mathrm{ft})$ diameter hole that was steel cased with bentonite at the bottom. The casing was pulled a few $\mathrm{ft}$, and a $0.3-\mathrm{m}(1-\mathrm{ft})$ layer of sand was placed at the bottom to reduce the chance of the VZMS assembly coming to contact with the bentonite. The VZMS assembly was lowered to the bottom of the hole, and the water-content sensor was 
set against the borehole wall using its attached lever arm. The process of seating the sensor against the wall was monitored with the aid of a down-hole video system. Once the VZMS was placed satisfactorily, the assembly was grouted in place with a silica flour slurry. The grout was allowed to settle a few minutes, and a sand plug was added on top of the grout. If the grout had not drained to a firm condition, it was found that the sand penetrated into grout until a firm hole resulted. Once a firm bottom was obtained, as evidenced by the feel of the tag line used to monitor backfill placement, the hole was backfilled with bentonite as casing was being pulled to the depth of the next installation. At the level of the next VZMS assembly, less $0.3 \mathrm{~m}(1 \mathrm{ft})$, a $0.3-\mathrm{m}(1-\mathrm{ft})$ layer of sand was added the sensor assembly inserted. This methodology was repeated up to the 6.2-m (20.4-ft) bgs depth, where the backfill materials were switched to sand and native materials. A PNNL soil WFM was installed at 6 bgs and extends to within $20 \mathrm{~cm}(8 \mathrm{in}$.$) of ground surface.$

The sensor locations are listed in Table 1. Calibration tables are shown in Appendix A. The wellcompletion report is listed in Appendix B, where a complete listing of backfill materials, their precise placement, and depths of sensor assemblies is provided.

\section{Initial Data}

Data from Well C33600 are shown in Figures 6 through 11. The soil water pressure data are shown on Figure 6. Since the pressure sensor used to monitor pressure in the tensiometers senses ABSOLUTE pressure, the data exhibit considerable barometric noise. There is a barometric sensor on the data logger that will be used to correct the pressures for the barometric changes. However, it was determined that the barometric sensor is not correctly wired and is producing irrelevant results. In lieu of the actual barometric sensor, daily barometric averages of pressure as reported by the Hanford Meteorological Station (HMS), corrected for the altitude difference between the HMS and the 200E Area, were used.

It was expected that the pressure data would show larger fluctuations over time as a result of the effect of adding fairly large volumes of water with the silica flour grout during the backfilling process. This indicates that the backfilling process used may have resulted in rapid equilibration in pressure between the backfill material and the surrounding sediments. We have used dry backfill material in the past, and it has typically resulted in equilibration times of several weeks. The tensiometer installed at the $1.8-\mathrm{m}(15-\mathrm{ft})$ depth shows erratic behavior that is probably due to sensor malfunction, while the rest of the tensiometers give quite steady readings. Even so, all of the tensiometers give readings within the expected range. Continued monitoring will provide the data needed to determine if the backfill is in a state of equilibrium with the surrounding soil.

Figure 7 shows the total water potential at Well C33600. This is the sum of the matric potential as measured by the tensiometers and the gravitational potential resulting from height above the water table. The dashed line indicates the gravity head. The measured points are all slightly to the left of the gravity head line, indicating that unit gradient conditions exist at the site.

Figure 8 shows water content changes at depth. The unexpectedly high readings from the sensors at 66.4- and 68.9-m depths may be due to high salinity as discussed below. All of the water content sensors show very little variation over time, indicating that conditions in the borehole are at equilibrium. 
Figure 9 shows drainage as measured by the water flux meter. No drainage has occurred yet at the site. This is in agreement with Figure 10, which shows that no measurable precipitation has occurred at the site since installation of the sensors.

Figure 11 shows soil temperature changes with depth over time. The temperature profile for a single day is indicated in Figure 12. Both figures exhibit expected behavior, with soil temperatures becoming less variable as depth increases.

\section{Discussion}

The B Farm installation is the first installation of the VZMS in the sands and gravels at Hanford. Previous installations have been in finer textured materials or in rock. Information gained from the B Farm installation may provide guidance for modifying the electrode geometry to better track changes in water content. A preliminary examination of the data collected at the B110 borehole indicates abnormally high water-content readings at the 66.4- and 68.9-m (218-, and 226-ft) depths. A similar behavior has been observed in the laboratory when saline solutions greater than $200 \mathrm{mS} / \mathrm{m}(2 \mathrm{mmho} / \mathrm{cm})$ were used for calibrating the sensors. Thus, adding a salinity sensor into the VZMS sensor assembly is recommended. Also having estimates of the electrical conductivity of the soil water-solution samples could be useful. These data are obtainable once the vacuum lysimeters are activated. 

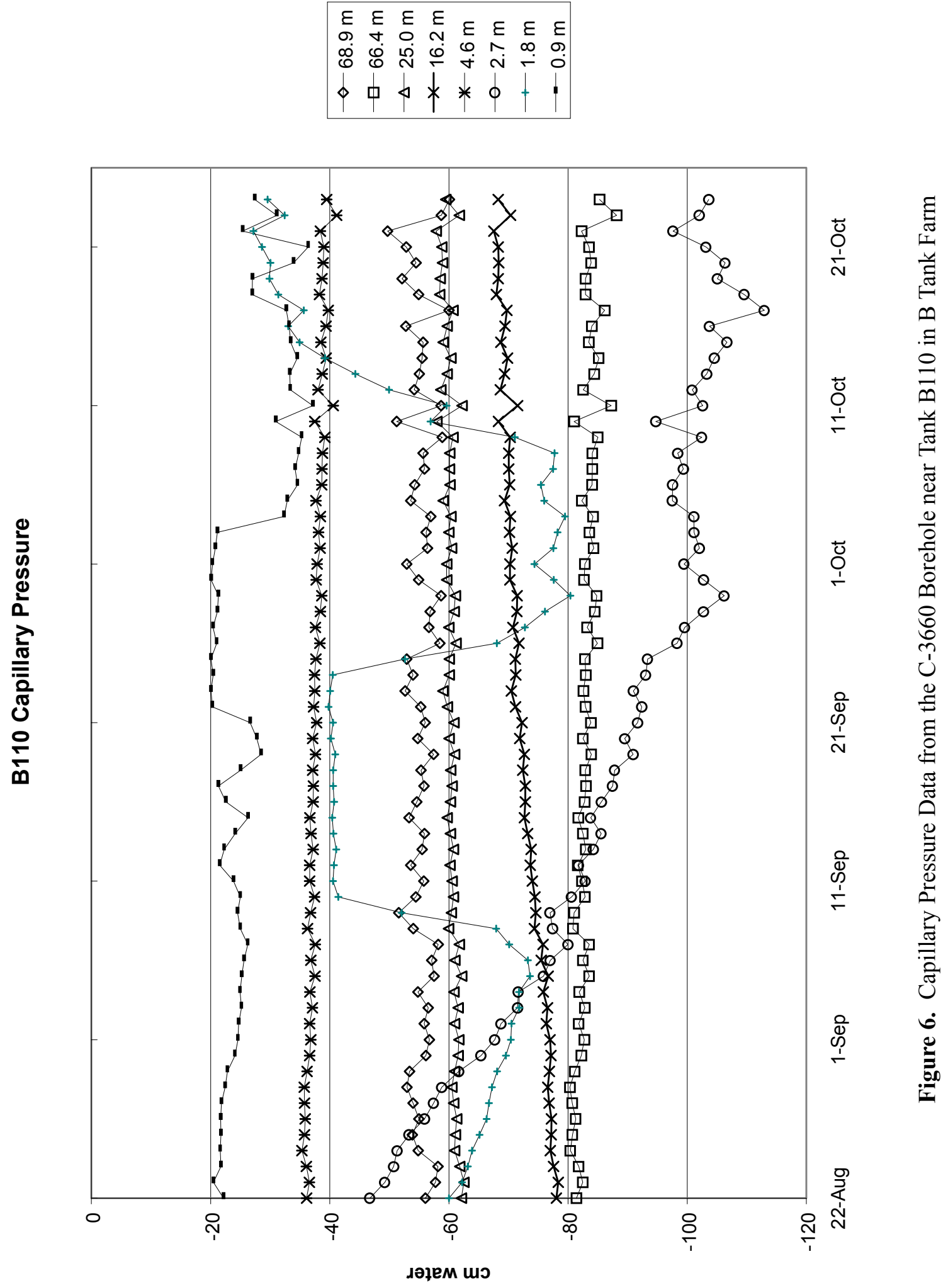


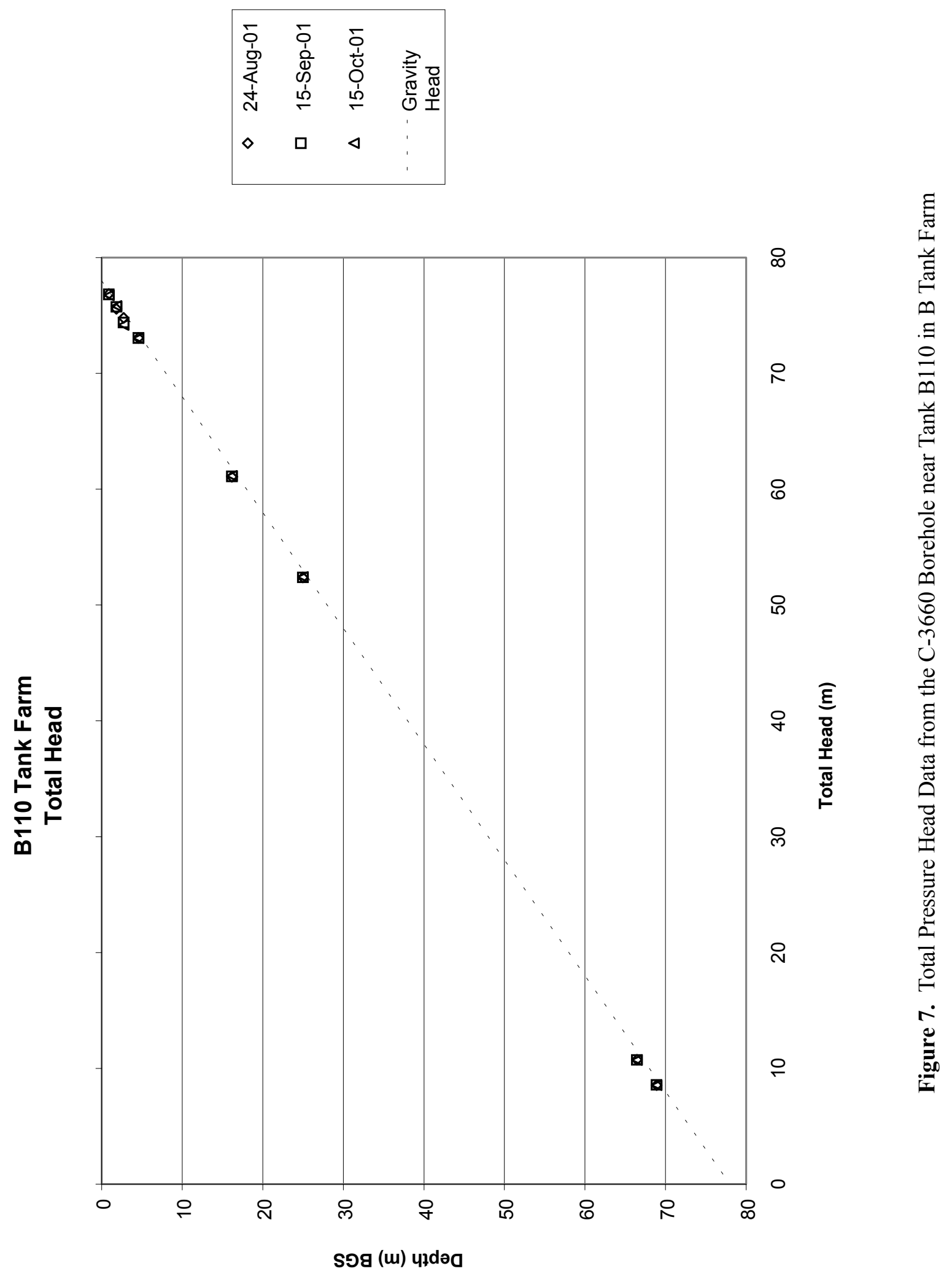




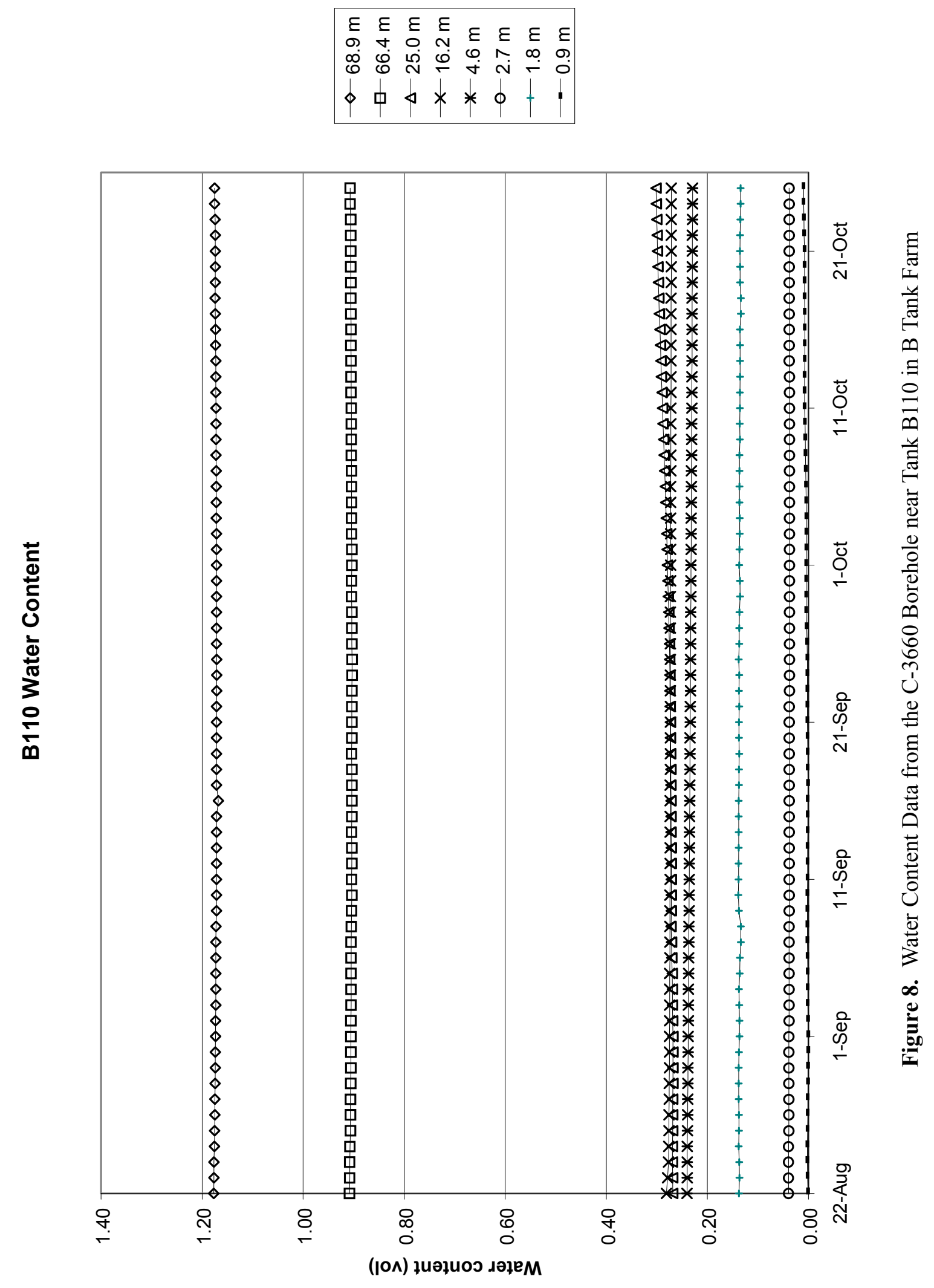




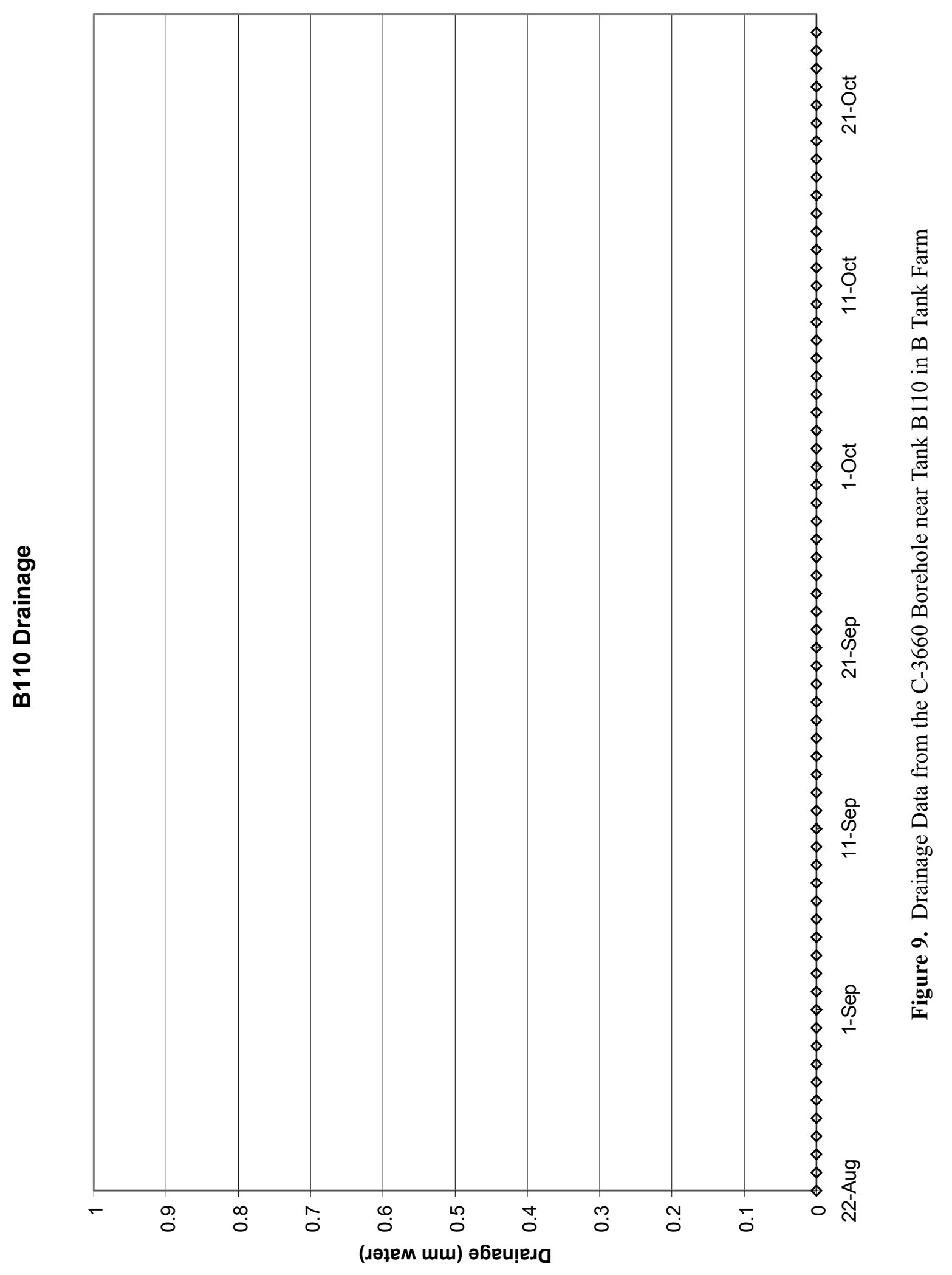




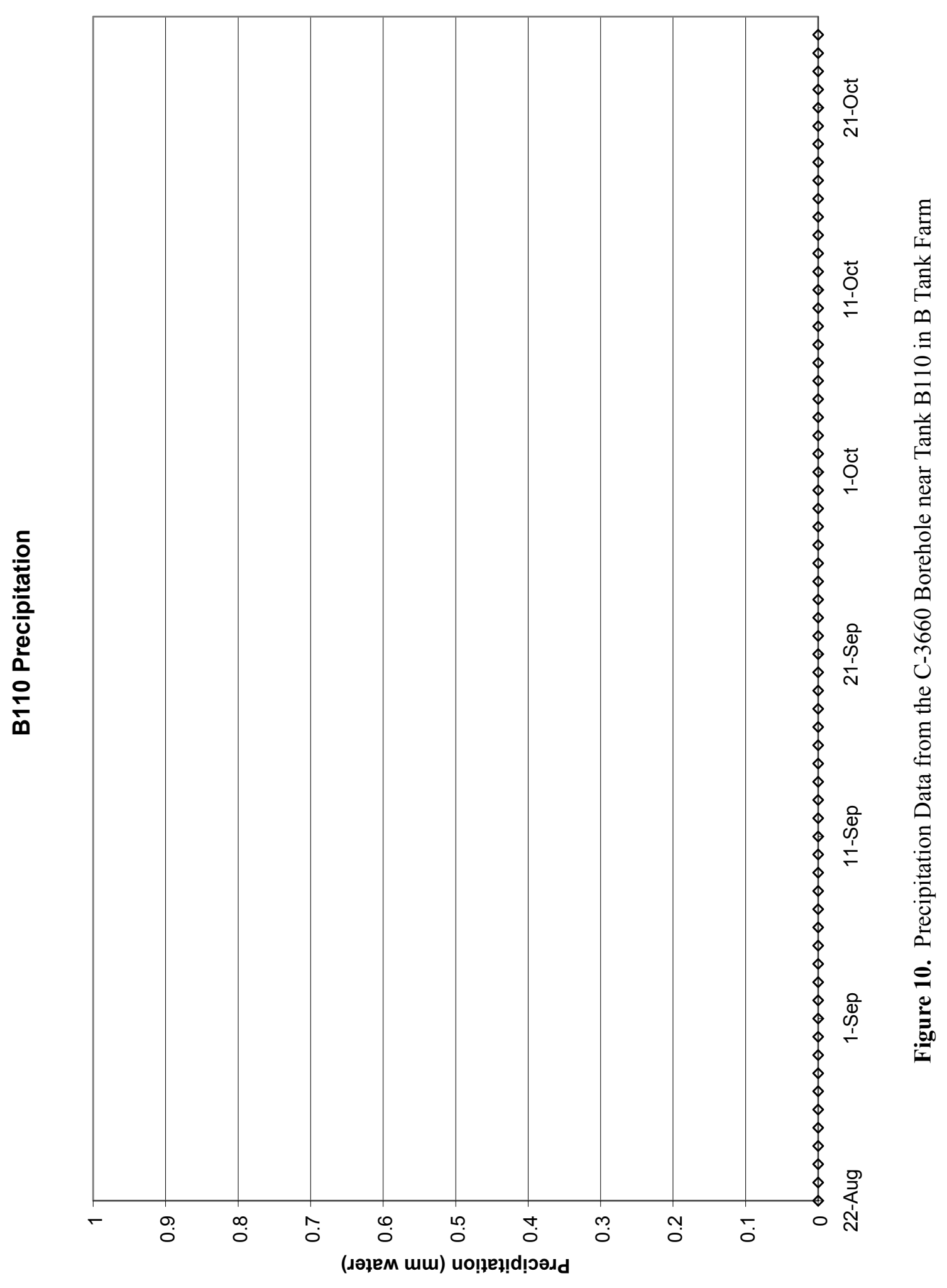



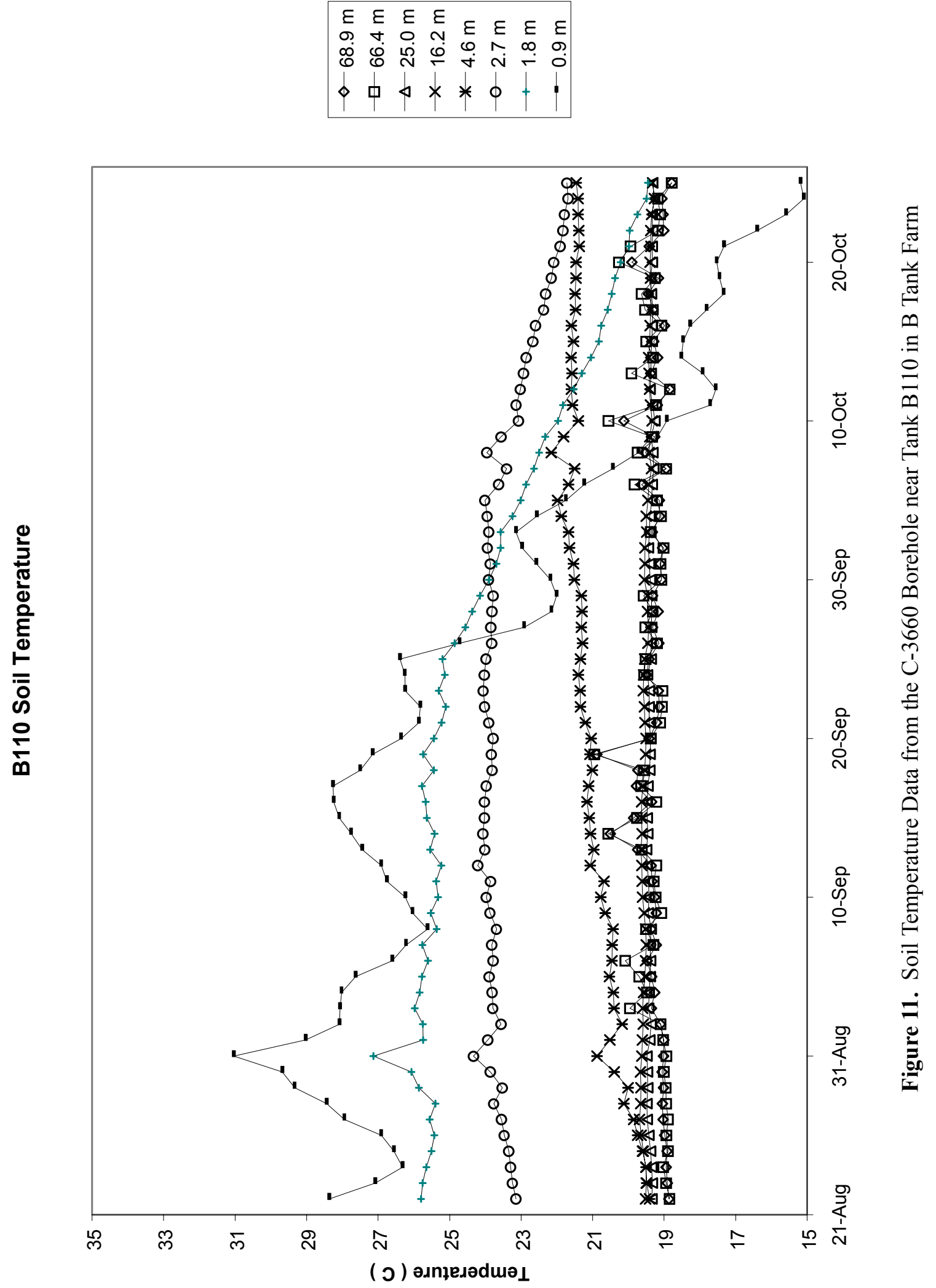


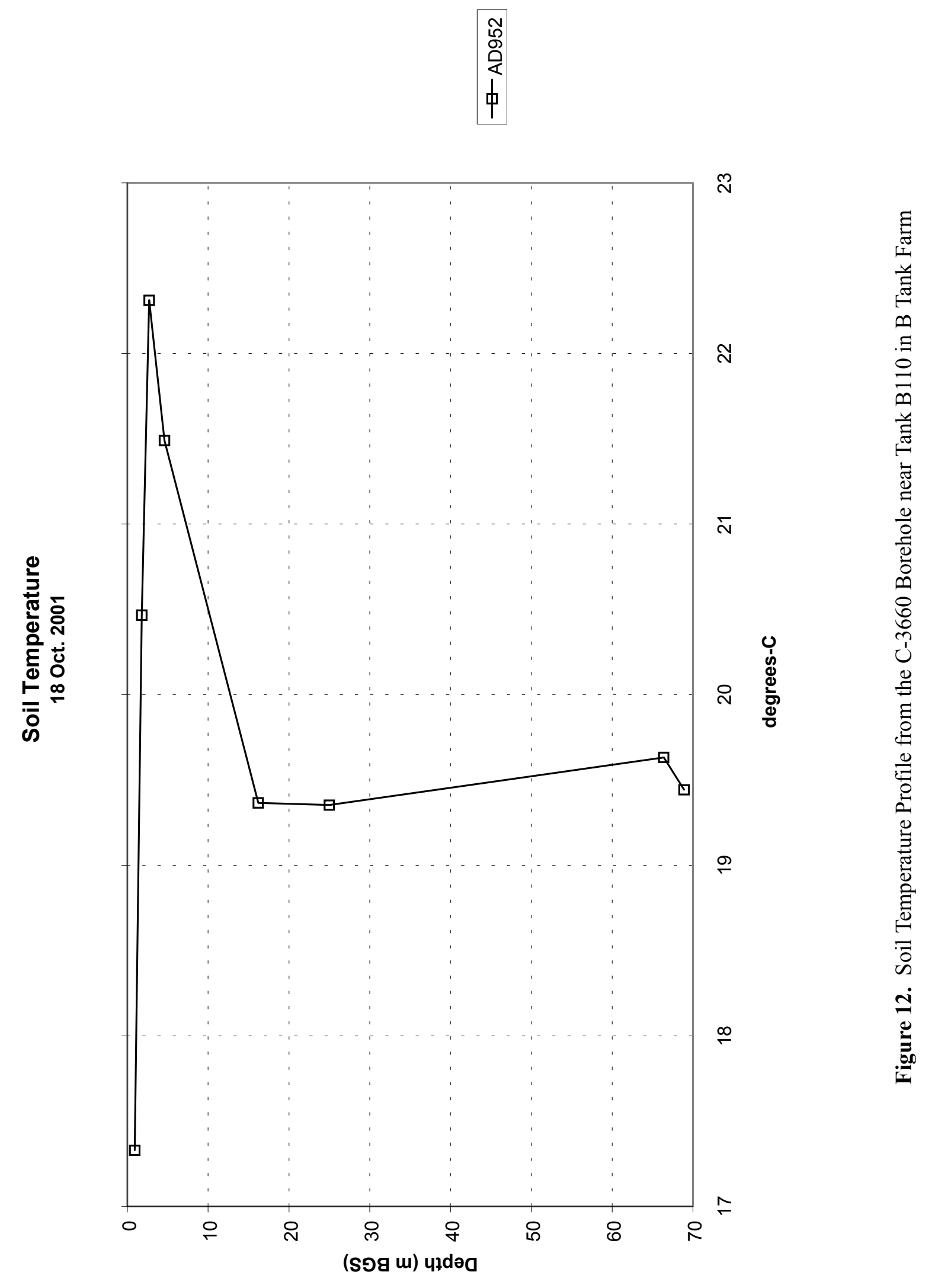


The tensiometers used in the B Farm installation are of a new design. The new design was done to provide a surface completion such that no pipe or casing would protrude above ground surface. Previous VZMS installations had access tubes from the tensiometers that protruded above ground surface. The access tubes provided for refilling and purging gases from the tensiometer. However, experience has shown that the tensiometers were capable of operating over extended periods without accumulating excessive volumes of soil gases. This experience led to the new design. Thus, it is recommended that the performance of the new design be evaluated for possible further improvements. After the B Farm installation, the design of the tensiometer has been simplified, although it is still more complex than the original advanced tensiometer design.

The inclusion of temperature sensors into the VZMS assembly is also a first. These data will be important to evaluating sensor behavior and evaluating chemical-transport behavior. The solid-state sensors were chosen because their current output provided a low noise signal and a reliable interface with the data logger.

Overall, the performance of the B Farm VZMS has and will continue to provide designs that are more advanced for tank-farm monitoring systems. Also it is expected that as data become available and are used by others, additional sensors may be added to the VZMS. 


\section{References}

CH2M Hill Hanford Group, Inc. (CHG). 2000. Site Specific SST Phase 1 RFI/CMS Work Plan Addendum for WMA B-BX-BY, RPP-6072, Rev.1, Richland, Washington.

Hubbell, J. M., and J. B. Sisson. 1996. "Portable tensiometer use in deep boreholes.” Soil Sci. 161: $376-381$.

Hubbell, J. M., and J. B. Sisson. 1998. “Advanced Tensiometer for shallow or deep capillary pressure measurements." Soil Sci. 163: 271-277.

Reece, C. F. 1996. "Evaluation of a line heat dissipation sensor for measuring soil matric potential." Soil Sci. Soc. Am. J. 60: 1022-1028.

Sisson, J. B., and J. M. Hubbell. 1999. "Capillary pressure to depths of 30 meters in fractured basalt and sedimentary interbeds," pp 855-865. In: M. Th. van Genuchten, F. J. Leij and L. Wu. (eds.), Proceedings of the International Workshop on Characterization and Measurement of the Hydraulic Properties of Unsaturated Porous Media. Oct 22-24, 1997, Riverside, California. University of California, Riverside Press.

Ward, A. L., G. W. Gee, and S. O. Link. 1997. Hanford Prototype-Barrier Status Report: FY 1997, PNNL-11789, Pacific Northwest National Laboratory, Richland, Washington. 


\section{APPENDIX A Calibration Data for VZMS Sensors}




\section{Appendix A}

Table A.1. Calibration Data from VZMS Sensors

\begin{tabular}{|c|c|c|c|c|c|}
\hline \multirow{3}{*}{$\frac{\text { Depth ID }}{\text { A }}$} & \multicolumn{5}{|c|}{ Modified CS505 Water Content Sensor $\left(m^{\wedge} 3 / m^{\wedge} 3\right)$} \\
\hline & Placement Depth & Slope & Intercept & \multicolumn{2}{|c|}{ "Location" on data logger } \\
\hline & 226 & 1.6246 & -1.2581 & 1 & \\
\hline $\mathrm{B}$ & 218 & 1.2796 & -1.0101 & 2 & \\
\hline $\mathrm{C}$ & 82 & 1.4476 & -1.1162 & 3 & \\
\hline $\mathrm{D}$ & 53 & 1.3578 & -1.0694 & 4 & \\
\hline E & 15 & 1.6796 & -1.3008 & 5 & \\
\hline $\mathrm{F}$ & 9 & 1.7014 & -1.3238 & 6 & \\
\hline G & 6 & 1.1908 & -0.9637 & 7 & \\
\hline \multirow[t]{3}{*}{$\mathrm{H}$} & 3 & 1.5409 & -1.2083 & 8 & \\
\hline & & & & & \\
\hline & \multicolumn{4}{|c|}{ Solid State Temperature Sensors degree-C } & \\
\hline Depth ID & Placement Depth & Slope & Intercept & & \\
\hline A & 226 & 4 & -273 & 9 & \\
\hline $\mathrm{B}$ & 218 & 4 & -273 & 10 & \\
\hline $\mathrm{C}$ & 82 & 4 & -273 & 11 & \\
\hline $\mathrm{D}$ & 53 & 4 & -273 & 12 & \\
\hline $\mathrm{E}$ & 15 & 4 & -273 & 13 & \\
\hline $\mathrm{F}$ & 9 & 4 & -273 & 14 & \\
\hline G & 6 & 4 & -273 & 15 & \\
\hline \multirow[t]{3}{*}{$\mathrm{H}$} & 3 & 4 & -273 & 16 & \\
\hline & & & & & \\
\hline & \multicolumn{4}{|c|}{ Tensiometer Pressure Sensor Motorola MPX4250A (cm-H20) } & \\
\hline Depth ID & Placement Depth & Slope & Intercept & & \\
\hline $\mathrm{A}$ & 226 & 0.5 & 100 & 17 & \\
\hline $\mathrm{B}$ & 218 & 0.5 & 100 & 18 & \\
\hline $\mathrm{C}$ & 82 & 0.5 & 100 & 19 & \\
\hline $\mathrm{D}$ & 53 & 0.5 & 100 & 20 & \\
\hline $\mathrm{E}$ & 15 & 0.5 & 100 & 21 & \\
\hline $\mathrm{F}$ & 9 & 0.5 & 100 & 22 & \\
\hline G & 6 & 0.5 & 100 & 23 & \\
\hline $\mathrm{H}$ & 3 & 0.5 & 100 & 24 & \\
\hline Barometer & & 0.5 & 100 & 25 & \\
\hline Flux & 9 & & & 26 & \\
\hline & & & & & \\
\hline & & & & & \\
\hline & & & & & \\
\hline & & & & & \\
\hline & & & & & \\
\hline
\end{tabular}


AP PENDIX B

Duratek Water Well Report for C-3360 (299E3 3-46) 


\section{Duratek \\ Federal services}

August 20, 2001
Duratek Federal Services, Inc. Northwest Operations 345 Hills street Richland, Washington 99352 (509) 376-7055 - Phone (509) $372-1435$ - Fax

MGG-01-1616

Mr. Joe A. Caggiano

State of Washington

Department of Ecology

1315 West $4^{\text {th }}$ Avenue

Kennewick, Washington 99336

Dear Mr. Caggiano:

\section{WATER WELL REPORT}

Enclosed is a Water Well Report for geotechnical boring C3360 (299-E33-46). This well is located in the 200 East Area, B Tank Farm. Boring C3360 was completed per WAC 173-160 requirements and discussions with the State of Washington Department of Ecology.

Please reference Start Card number S00615 (Notice of Intent to Construct a Geotechnical Soil Boring).

Should you have any questions, please contact me at (509) 372-8029.

Very truly yours,

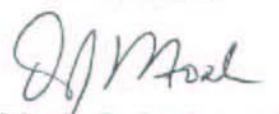

Martin G. Gardner, Manager

Sampling and Well Services

jal

Enclosure

$\begin{array}{ll}\text { CHG } & \text { - J. E. Auten } \\ & \text { A. J. Knepp } \\ & \text { H. A. Sydnor } \\ \text { DFSNW } & - \text { K. D. Reynolds } \\ & \text { D. E. Skoglie } \\ & \text { S. H. Worley } \\ & \text { MGG File/LB } \\ & \text { CHG } / 772028 / 305\end{array}$


File Original with Department of Ecology Second Copy - Owner's Copy Third Copy - Driller's Copy
WATER WELL REPORT

STATE OF WASHINGTON
Notice of Intent $S 00515$

UNIQUE WELL $1.0 .2 .299-E 33-46$ Water Plight Permit Na N/A PAGR I of 3

(1) OWNER: Name U.S. Departnent of Energy Address 825 Jadwin Ave., Richland, WA 99352

7 LOCATION OF WELL: County Benton

(2a) STREET ADDRESS OF WELL: (or nearest address) Hanford Site TAX PARCEL NO: N/A

\begin{tabular}{|c|c|c|c|c|}
\hline (3) & PROPOSED USE: & $\begin{array}{l}\square \text { Domestic } \\
\square \text { Irrigation } \\
\square \text { DeWater }\end{array}$ & $\begin{array}{l}\square \text { Industrial } \\
\square \text { Test Welt }\end{array}$ & $\begin{array}{l}\text { Dunicipa! } \\
\text { Other }\end{array}$ \\
\hline (4) & TYPE OF WORK: & $\begin{array}{l}\text { Qwner's number of } \\
\otimes \text { New Well } \\
\square \text { Deepened } \\
\square \text { Reconditioned } \\
\square \text { Decommission } \\
\end{array}$ & $\begin{array}{l}\text { well (if more than one) } \\
\text { Method: } \\
\square \text { Dug } \\
\text { X Cable } \\
\square \text { Aotary } \\
\end{array}$ & $\begin{array}{l}C 3360 \\
\square \text { Bored } \\
\square \text { Driven } \\
\square \text { Jetted } \\
\end{array}$ \\
\hline (5) & $\begin{array}{l}\text { DIMENSIONS: } \\
\text { Drilled_264.2 }\end{array}$ & $\begin{array}{l}\text { Diameter of well } \\
\text { feet. Depth of comp }\end{array}$ & $\begin{array}{l}11.75 \\
\text { leted well } 226.0\end{array}$ & in \\
\hline (6) & $\begin{array}{l}\text { CONSTRUCTION DE } \\
\text { Casing Installed: } \\
\text { Weided } \\
\square \text { Liner installed } \\
\square \text { Threaded }\end{array}$ & $\begin{array}{l}\text { TAILS } \\
13.375: \\
10.15:\end{array}$ & $\begin{array}{l}\text { Diam, from } 0 \\
\text { Diam, from } 0 \\
\text { Diam, from }\end{array}$ & $\begin{array}{l}\text { it to } \frac{121.3}{264.2} \\
\text { ti. to } \\
\text { th. to }\end{array}$ \\
\hline
\end{tabular}

Perforations:
Type of pertorator used $X$ No
SIZE of perforations

Sereens:

$\square$ Yes ¿NNo $\square$ K.Pac Location

Manutacturer's Name

Type

Siam. Slot Size Diam. Sor Size

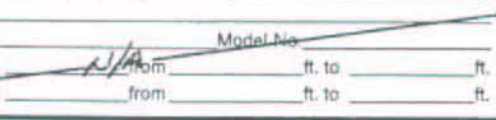

GravelFilter packed: $\square$ Yes XNo $\square$ Size of graveVsand Materiai piaced from__ th. to

\begin{tabular}{|c|c|c|}
\hline $\begin{array}{l}\text { Surface seal: } \\
\text { Materiair used in seal. }\end{array}$ & $\square$ Yes $X_{N_{0}}$ & To what depth? $\frac{\text { See As-Built }}{\text { Condition }}$ \\
\hline
\end{tabular}

Did any strata contain unusabie water? XY Yes $\square$ No

Type of water? $\quad N / A$ Depth of strata

(7) PUMP: Manufacturer's Name N/A Type: H.P.

(8) WATER LEVELS: Land-surface elevation above mean sea level 657.3 Static level $255 \mathrm{~g}$ th. below top of well Date 0.52601 it. Arlesian pressure __ Der square inch Date Artesian water is controlled by

(9) WELL. TESTS: Drawdown is amount water level is lowered beiow static level Was a pump test made? DYes $\forall$ No II yes, by whom?

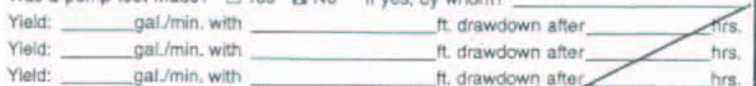

Recovery data (time taken as zero when purnp tumed off) (wateshosei measured from well top to water level)

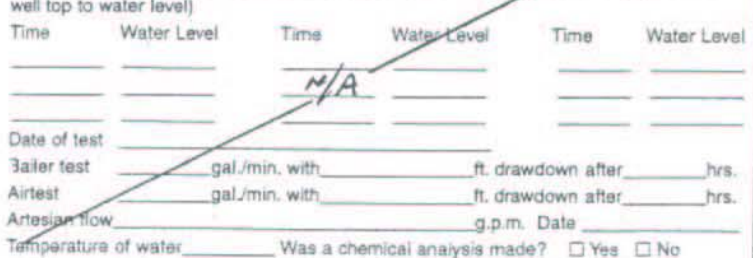

Tamiperature of water__ Was a chemicai anaiysis made? $\square$ Yes $\square$ No

ECY 050-1.20 (11/98)
SE $1 / 4$ SE $1 / 4 \mathrm{Sec} 34 \quad$ T 13 N.R. 26 wM $200 E$ Area, B Tank Farm

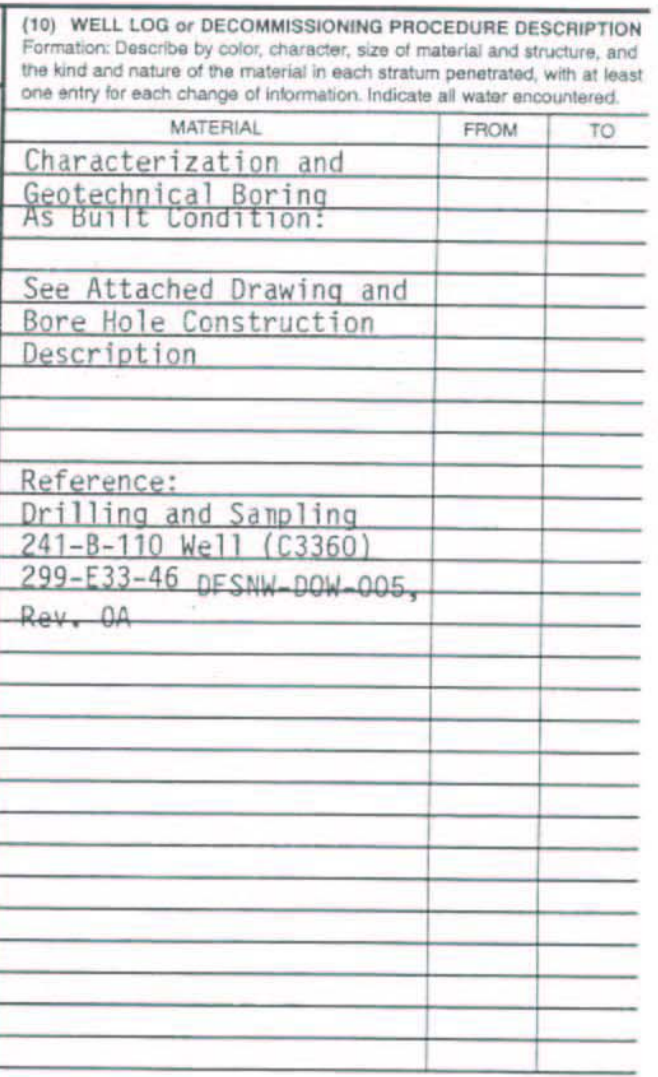

Work Startad_April 10, 2008bmplated July 31, 2001

WELL CONSTRUCTION CERTIFICATION:

I constructed and/or accept responsibility for construction of this well, and its compliance with all Washington well construction standards. Materials used and the information reported above are true to my best knowledge and beliet. Type or Print Name Ke Ily OI son License No. 1217

Trainee Name N/A License No

Driling Company Resonant SonicInt. (Signed) Sawid E. Shes lie Licanse No. 1580 Address $345 \mathrm{Hills}$ ST, Richland, WA 99.35? Contractor's

Registration No. RSONI $\star 016 L 5$ Date 081601 (USE ADOITIONAL SHEETS IF NECESSARY)

Ecology is an Equal Opportunity and Affirmative Action employer. For specia: accommodation needs, contact the Water Resources Program at (360) 407. 6600 . The TDD number is $(360)$ 407-6006. 
WATER WELL REPORT

STATE OF WASHINGTON

Page 2 of 3

As Built Condition:

1) $133 / 8$ inch casing was drilled to a depth of $121.3 \mathrm{ft} \mathrm{BGS}$. Sediment samples were collected by split spoon and grab methods. Radiological contamination was noted from $44.7 \mathrm{ft} \mathrm{BGS} \mathrm{to} 86.2 \mathrm{ft}$ BGS utilizing field instrumentation.

2) Geophysical Logging and analysis was conducted (Gross gamma, Spectral High Purity GermaniumHpgE, and Neutron-Moisture) inside the $133 / 8$ casing annulus.

3) $103 / 4$ inch casing was drilled to a depth of $264.2 \mathrm{ft}$ BGS. Sediment samples were collected by split spoon and grab methods.

4) The water level was $255.9 \mathrm{ft}$ BGS (062601). A temporary screen was set, casing back pulled, and a water sample obtained.

5) Geophysical Logging and analysis was conducted (Gross gamma, Spectral High Purity GermaniumHpgE, and Neutron-Moisture) inside the $10 \% / 4$ casing annulus.

6) The geotechnical boring was decommissioned with sand to a depth of $253.7 \mathrm{ft}$ BGS while back pulling casing. Bentonite crumbles were placed to a depth of $228.3 \mathrm{ft} \mathrm{BGS}$ while back pulling casing. Sand (10-20) was placed to a depth of $227.9 \mathrm{ft} \mathrm{BGS}$.

7) Number 8 sensor array (Advanced Tensiometer, Solution Sampler, Heat Dissipation Sensor, and Water Content Sensor) was set @ a depth of $226 \mathrm{ft}$ BGS. Silica flout/sand was placed to a depth of $225.2 \mathrm{ft}$ BGS. Sand was placed to a depth of $223.7 \mathrm{ft}$ BGS. Bentonite pellets were added to a depth of $220.8 \mathrm{ft}$ BGS while back pulling casing.

8) Sand (10-20) was placed to a depth of $219.1 \mathrm{ft}$ BGS.

9) Number 7 sensor array (Advanced Tensiometer, Solution Sampler, Heat Dissipation Sensor, and Water Content Sensor) was set @ a depth of $218 \mathrm{ft}$ BGS. Silica flour/sand was placed to a depth of $215.8 \mathrm{ft}$ BGS. Sand was placed to a depth of $211.7 \mathrm{ft}$ BGS while back pulling casing.

10) Bentonite crumbles were placed to a depth of $124.2 \mathrm{ft}$ BGS while back pulling casing. The remaining $10 \%$ inch casing was removed from the bore hole.

11) Bentonite crumbles were placed to a depth of $85.5 \mathrm{ft}$ BGS while back pulling the 13.375 inch casing.

12) Sand (10-20) was placed to a depth of $84.5 \mathrm{ft}$ BGS.

13) Number 6 sensor array (Advanced Tensiometer, Heat Dissipation Sensor, and Water Content Sensor) was set @ a depth of $82 \mathrm{ft} \mathrm{BGS.} \mathrm{Silica} \mathrm{flour/sand} \mathrm{was} \mathrm{placed} \mathrm{to} \mathrm{a} \mathrm{depth} \mathrm{of} 79.6 \mathrm{ft}$ BGS.

14) Bentonite crumbles were placed to a depth of $56.5 \mathrm{ft}$ BGS while back pulling casing.

15) Sand (10-20) was placed to a depth of $55.3 \mathrm{ft}$ BGS.

16) Number 5 sensor array (Advanced Tensiometer, Heat Dissipation Sensor, and Water Content Sensor) was set @ a depth of $53 \mathrm{ft} \mathrm{BGS.} \mathrm{Silica} \mathrm{flour/sand} \mathrm{was} \mathrm{placed} \mathrm{to} \mathrm{a} \mathrm{depth} \mathrm{of} 45.3 \mathrm{ft} \mathrm{BGS}$.

17) Bentonite crumbles were placed to a depth of $20.4 \mathrm{ft}$ BGS while back pulling casing.

18) Sand (8-12) was placed to a depth of $16 \mathrm{ft}$ BGS

19) Number 4 sensor array (Advanced Tensiometer, Heat Dissipation Sensor, and Water Content Sensor) was set @ a depth of $15 \mathrm{ft}$ BGS. Silica flour/sand was placed to a depth of $11.2 \mathrm{ft}$ BGS. Natural fill (bore hole collapse to $10 \mathrm{ft}$ BGS).

20) Number 3 sensor array (Advanced Tensiometer, Heat Dissipation Sensor, and Water Content Sensor) was set @ a depth of $9 \mathrm{ft}$ BGS. Sand (10-20) was placed to a depth of 7.2 $\mathrm{ft}$ BGS.

21) Number 2 sensor array (Advanced Tensiometer, Heat Dissipation Sensor, and Water Content Sensor) was set@ a depth of $6 \mathrm{ft}$ BGS. Sand (10-20) was placed to a depth of $4.7 \mathrm{ft}$ BGS.

22) Number 1 sensor array (Advanced Tensiometer, Heat Dissipation Sensor, Water Content Sensor, and Water Flux Meter) was set@ a depth of $3 \mathrm{ft} \mathrm{BGS} / 2 \mathrm{ft}$ BGS. Sand (10-20) was placed to a depth of 0.0 ft BGS.

23) The Sensor Arrays were wired and site secured. 


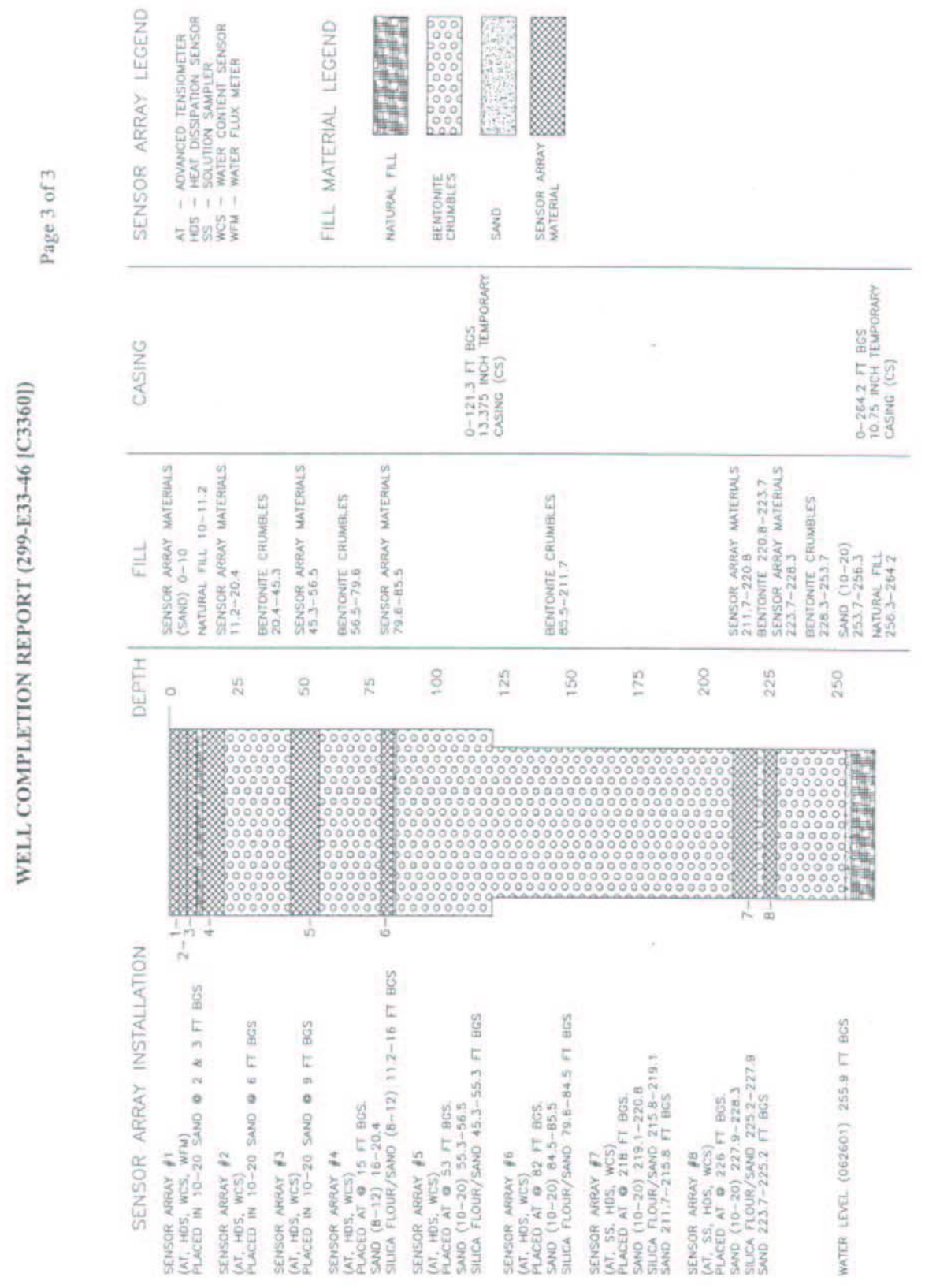

B. 4 